\title{
Ecos do II Congresso Ibero-Americano de Municipios
}

\author{
Ainda sôbre o Congresso Ibero-Americano de Municipios, \\ realizado no periodo de 19 de maio último, em Lisboa, temos o \\ prazer de reproduzir para nossos leitores a nota de "O Mundo \\ Português", de 28/6/59, que como já o fizeram outros periódi- \\ cos exalta a vitória da tese sustentada pelo delegado brasileiro, \\ Dr. Manoel Caetano Bandeira de Mello, Diretor do Servi- \\ ço de Documentação do D.A.S.P.
}

\section{ELIMINEMOS TOODAS AS BARREIRAS ENTRE BRASILEIROS E LUSITANOS}

Comovido o jornalista M. C. Bandeira de Mello com a «onda de carinho» com que os portuguêses envolvem os brasileiros em visita a Portugal - Notável a colaboração lusa para vitória da tese sustentada no Congresso Internacional de Municipios, em Lisboa, pelo ilustre Diretor de Divulgação do D.A.S.P.

Conforme noticiamos por ocasião de seu embarque para a Europa, participou o jornalista Manoel Caetano Bandeira de Mello, diretor do Serviço de Documentação do D.A.S.P., do II Congresso Ibero-Americano de Municipįos, integrando a delegação brasileira como representante daquele órgão da Presidência da República. A atuação dêste nosso ilustre colega no conclave foi de tal maneira brilhante, que ainda agora $\delta$ Professor MARCElo CaEtano, reitor da Universidade de Lisboa, lhe dirigiu carta enaltecendo sua contribuição como relator geral de um dos quatro temas do certame.

Regressando ao Rio, há dias, após visitar também outros países do Velho Mundo, assim falou à nossa reportagem o Diretor de Divulgação do Departamento Administrativo do Serviço Público, dando suas impressões do Congresso de Municípios e do contato mantido com a gente portuguêsa.

"Constituiu um êxito consagrador para o Brasil o II Congresso Ibero- Americano de Municípios, realizado em Lisboa, no período de 14 a 19 de maio último. A delegação brasileira, como bฯm acentuou o Deputado Lou RIVAL Batista que tão eficientemente representou o Congresso Nacional naquele importante certame, logrou ver aprovada e mesmo consagrada a tise que ali defendeu, bem como as posições assumidas em nome da Associação Brasileira de Municipios". 


\section{ACLAMAÇÃO À TESE BRASILEIRA}

- De minha parte - prossegue o Dr. Manoel Caetano Bandeira de Mello - levei a contribuição técnica e a experiência do D.A.S.P. dentro das diretrizes traçadas pelo Dr. JoÃo Guilherme de Aragão, Dinotor-Geral dêste Departamento, logrando ver aprovada, por aclamação, tôda conclusão que elaborei nas Comissões Técnicas e, em seguida, levei à alta consideração do Congresso.

Continuou o Diretor do Serviço de Documentação do D.A.S.P.:

- o que a todos os brasileiros calou profundamente, foi o carinho extremo de que em todos os momentos nos cercaram os portuguêses.

Até mesmo a nossa contribuição técnica, referente ao Estatuto dos Funcionários para Administração Municipal, teve como prova dessa alta distinção de que é em Portugal sempre alvo o Brasil, a colaboração expontânea e precisa, logo igualmente aclamada pelo Plenário, do Brigadeiro França Borges, ilustre Presidente da Câmara/Municipal de Lisboa, no tocante às garantias de previdência social a serem asseguradas aos servidores. Do mesmo modo, o Dr. Manoel Ferreira dos Santos, Diretor de Orçamento de Lisboa, sempre nos assistiu com elevado espírito de colaboração e a admirável saber técnico pelo qual the serei sempre profundamente reconhecido. Mas se fôra citar todos os portuguêses que se tornaram credores da nossa mais profunda gratidão, não teria término esta entrevista.

\section{ONDA DE CARINHO}

Por tôda parte - conclui o Dr. Manoel Caetano Bandeira de Mello em Lisboa, na Universidade de Coimbra, no Pôrto, onde sempre usamos da palavra, fomos envolvidos de maneira comovente, pela onda de carinho do povo português. Sentiamos-nos, todos, como se estivéssemos no Brasil, em nossa própria casa, e esta é a prova humana e eloqüente da eternidade que constituiu e constitui a marca da comunidade luso-brasileira, para cuja defesa e perpetuação sou de parecer que se devem eliminar quaisquer barreiras protocolares, de modo a que os portuguêses se sintam cidadôes brasileiros no Brasil, assim como nos sentimos portuguêses na Pátria berço da nossa nacionalidade. 